\title{
Technology and Challenges in Additive Manufacturing of Duplex Stainless Steels
}

\section{Rayappa Shrinivas Mahale 1,*, Shashanka Rajendrachari ${ }^{2}$, Shamanth Vasanth ${ }^{1}$, Hemanth Krishna ${ }^{1}$, Nithin Somenahalli Kapanigowda ${ }^{1}$, Sharath Peramenahalli Chikkegowda ${ }^{3}$, Adarsh Patil ${ }^{4}$}

1 School of Mechanical Engineering, REVA University, Bengaluru, Karnataka, India; rayappamahale@gmail.com (R.S.M.); shamanth.v@ reva.edu.in (S.V.); hemanth.k@reva.edu.in (H.K.); nithinsk67@gmail.com (N.S.K.);

2 Department of Metallurgical and Materials Engineering, Bartin University, Bartin, Turkey; shashankaic@gmail.com (S.R.);

3 Department of Metallurgical and Materials Engineering JAIN Deemed to be University, Bengaluru, Karnataka, India; pcsharath1988@gmail.com (S.P.C.);

4 School of Mechanical Engineering, KLE Technological University, Hubballi, Karnataka, India; adarsh@kletech.ac.in (A.P.);

* Correspondence: rayappamahale@gmail.com (R.S.M.);

Scopus Author ID 57220036422

Received: 1.03.2021; Revised: 5.04.2021; Accepted: 8.04.2021; Published: 26.04.2021

Abstract: Duplex stainless steels (DSS) comprise equivalent proportions of ferrite $(\alpha)$ and austenite $(\gamma)$ and exhibit excellent integration of mechanical and corrosion properties. The ferrite matrix provides better strength and stress corrosion resistance, whereas the austenite matrix accounts for good pitting corrosion resistance and toughness. Duplex stainless steels are widely utilized in the chemical industry, oil refineries, and machine industries. Direct energy deposition (DED) and powder bed fusion (PBF) are the two additive manufacturing techniques widely used for metals. This article covers the technologies like processing DSS by selective laser melting (SLM), variation in mechanical and microstructural properties of duplex stainless steels manufactured by additive manufacturing technique, and challenges of additive manufacturing processes.

Keywords: duplex stainless steels (DSS); metal additive manufacturing; selective laser sintering (SLS); selective laser melting (SLM); fused deposition modeling (FDM).

(C) 2021 by the authors. This article is an open-access article distributed under the terms and conditions of the Creative Commons Attribution (CC BY) license (https://creativecommons.org/licenses/by/4.0/).

\section{Introduction}

The American Society for Testing and Materials (ASTM) F2792 describes additive manufacturing (AM) as "a process of joining materials to make objects from three-dimensional (3D) model data, usually layer upon layer, as opposed to subtractive manufacturing methodologies." It is possible to divide metal additive manufacturing technologies into two parts: (1) The direct way in which the metal powder fully melts to form the final part. (2) An indirect way to attach metal powder particles with a binder. Post-processing is important for both direct and indirect methods to achieve the desired density [1]. The classification of metal additive production processes is shown in Figure 1.

Table 1. Nomenclature.

\begin{tabular}{c|c} 
DSS & Duplex Stainless Steels \\
\hline DED & Direct Energy Deposition \\
\hline PBF & Powder Bed Fusion \\
\hline SLM & Selective Laser Melting \\
\hline SLS & Selective Laser Sintering \\
\hline AM & Additive Manufacturing
\end{tabular}




\begin{tabular}{c|c} 
EBSD & Electron Back Scattered Diffraction \\
\hline SAF & Sandvik austenitic-ferritic \\
\hline Epit & Pitting Potential \\
\hline VSCE & Voltage at Saturated Calomel Reference Cell \\
\hline DDPM & Dual Drive Planetary Mill
\end{tabular}

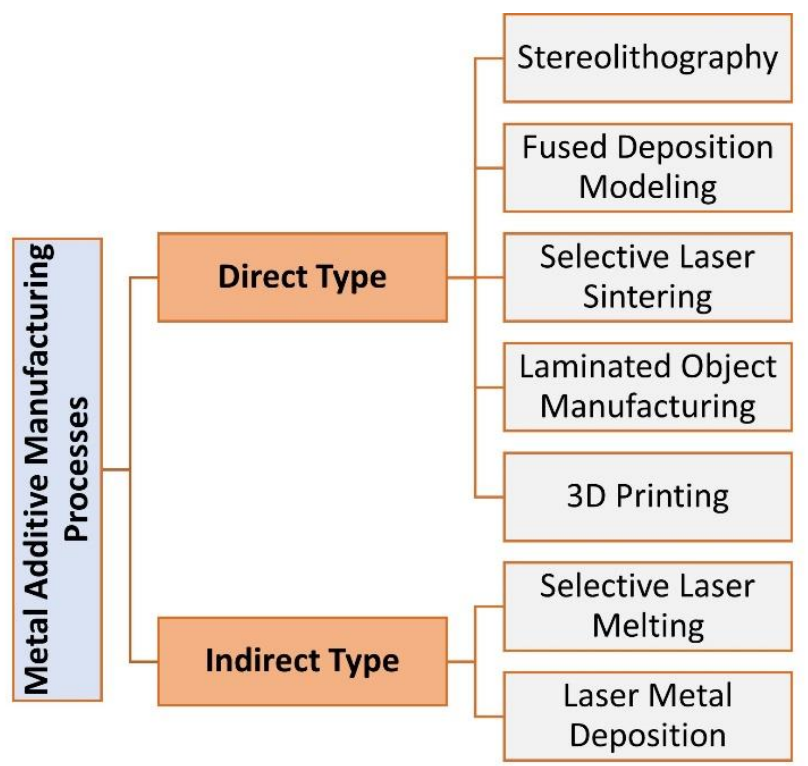

Figure 1. Classification of metal additive manufacturing processes [1].

\section{Selective Laser Melting}

In this process, the laser beam that passes through a lens system is reflected on the scanner mirror's platform surface. The mirrors regulate the laser beam's spot movements in the direction of $\mathrm{X}$ and $\mathrm{Y}$. The platform moves a step down when the first powder layer is selectively melted. The recoating device pushes a fresh layer of powder from the powder dispenser to the top of the previously built layer surface. The laser melting process continues [2]. The Argon (inert) gas fills the SLM system chamber. In certain machines, argon gas is used to prevent the oxidation of metals during melting and solidification. Advantages and disadvantages of SLM were reported by Bartolo et al. elsewhere [3].

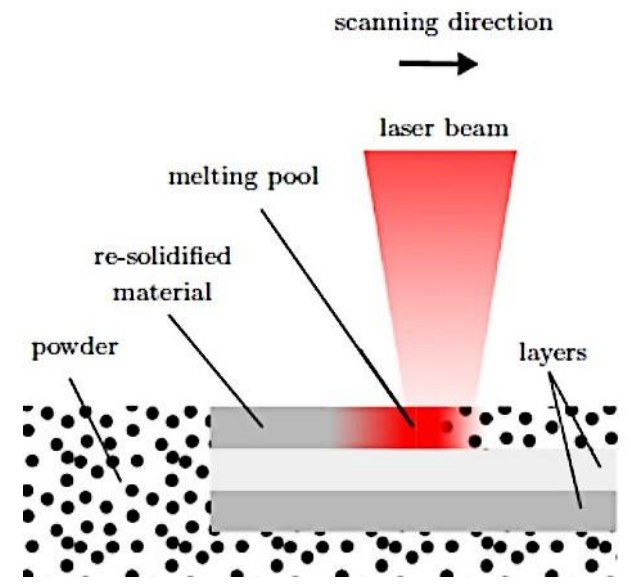

Figure 2. Selective laser melting technique [2].

\section{Mechanical and Microstructural Properties of SLS Processed Duplex Stainless Steels}

Hengsbach et al. used DSS powder UNS S31803 that has a mean particle size of 22.7 $\mu \mathrm{m}$ [4]. The DSS grade chemical composition was $0.02 \mathrm{C}, 1.54 \mathrm{Mn}, 0.38 \mathrm{Si}, 5.46 \mathrm{Ni}, 2.76$ 
Mo, 22.78 Cr, 0.16 N, 0.02 P with Fe equilibrium [4]. Using an SLM $280^{\mathrm{HL}}$ fitted with a 400 Watt yttrium fiber laser, the specimens were prepared. To stop the consequences of notches, the SLM specimens were grounded to $15 \mu \mathrm{m}$ for mechanical testing. The samples were heattreated for 5 minutes in evacuated quartz glass tubes with temperatures varying from $900{ }^{\circ} \mathrm{C}$ to $1200^{\circ} \mathrm{C}$ in steps of $50^{\circ} \mathrm{C}$ and then quenched in cold water. The authors found that the relative density of the specimens processed by SLM was approximately $99.6 \%$.

The electron backscattered diffraction (EBSD) maps are well described by Hengsbach et al. in their previous publication, along with the EBSD image [4]. These elongated grains indicate that the isotropic microstructure results in epitaxial grain growth. In the as-built state, they reflect a completely ferritic microstructure. Authors have found that the formation of austenite and other precipitations is completely suppressed in the as-built state [4]. The recrystallized microstructure in the solution annealed samples shows the formation of ferrite and austenite. The austenite content reaches $34 \%$ at $1000^{\circ} \mathrm{C}$ and reaches its lowest volume at $1200^{\circ} \mathrm{C}$, resulting in converting austenite into ferrite.

Suvi Papula et al. used DSS powder SAF 2205 and performed SLM. Table 2 refers to the chemical composition of the powder. The AM method's efficiency depends solely on the quality of the powder, as per the author's perspective.

Table 2. Chemical composition of SAF2205 powder [5].

\begin{tabular}{c|c|c|c|c|c|c|c|c|c|c} 
Element & $\mathbf{N i}$ & $\mathbf{C r}$ & $\mathbf{M o}$ & $\mathbf{M n}$ & $\mathbf{S i}$ & $\mathbf{N}$ & $\mathbf{C}$ & $\mathbf{P}$ & $\mathbf{S}$ & $\mathbf{F e}$ \\
\hline wt $\%$ & $5-6$ & $22-23$ & $2.8-3.6$ & 2.0 & 1.0 & $0.15-0.21$ & 0.03 & 0.03 & 0.015 & bal.
\end{tabular}

2205 DSS powder with a particle size between 15 and $45 \mu \mathrm{m}$ [5] was used by Suvi Papula et al. The particles of the powder are circular in shape. Based on the parameters specified in table 3, SLM was performed.

\begin{tabular}{|c|c|c|c|c|c|}
\hline $\begin{array}{c}\text { Laser Power } \\
(\mathrm{W})\end{array}$ & $\begin{array}{c}\text { Scan Speed } \\
(\mathrm{mm} / \mathrm{sec})\end{array}$ & $\begin{array}{c}\text { Layer Thickness } \\
(\mu \mathrm{m})\end{array}$ & $\begin{array}{c}\text { Hatch Spacing } \\
(\mu \mathrm{m})\end{array}$ & $\begin{array}{c}\text { Track Energy } \\
(\mathrm{J} / \mathbf{m m})\end{array}$ & $\begin{array}{c}\text { Laser Energy } \\
\text { Density }\left(\mathrm{J} / \mathbf{m m}^{3}\right)\end{array}$ \\
\hline 250 & 850 & 50 & 100 & 0.29 & 59 \\
\hline
\end{tabular}

The $250 \mathrm{~W}$ laser power was used to process SAF 2205 DSS, which in turn decreases porosity. The density obtained between the successive layers was 99.97 percent by $66^{\circ}$ rotation and 99.01 percent with the non-rotated scanning strategy in the scanning direction. By using a scanning technique with rotation in the scanning, minimal porosity is achieved between the layers.

The columnar grain morphology of as-built materials aligned in the direction of construction [5] is represented in Figures 3 (a) \& (b). Due to columnar grains' spread into consecutive layers, epitaxial growth is observed in the AM processed materials. The authors noted that the as-built material displays a completely ferritic solidification microstructure because of higher cooling speeds. Significant fractions of the austenite content were observed after successive heat treatment of the as-built samples. The high dislocation density of as-built DSS specimens is the main driving force behind the nucleation and recrystallization of austenite during the subsequent heat treatment. 


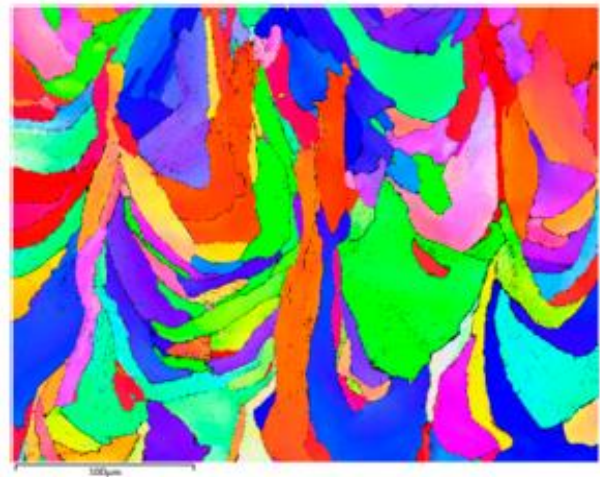

(a)

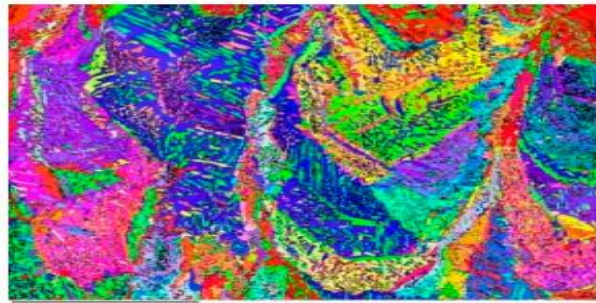

(c)

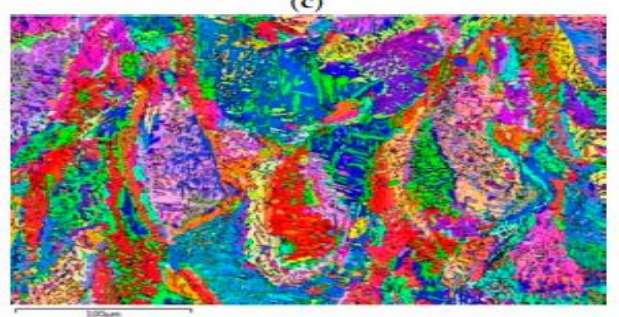

(e)

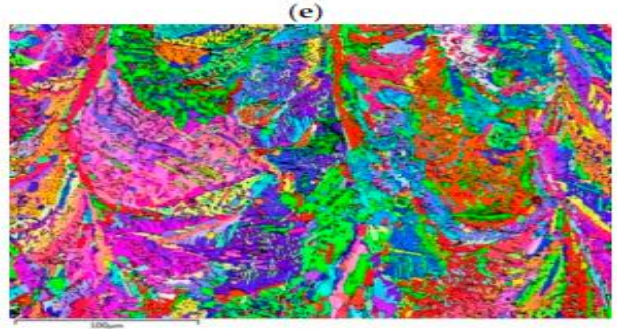

(g)

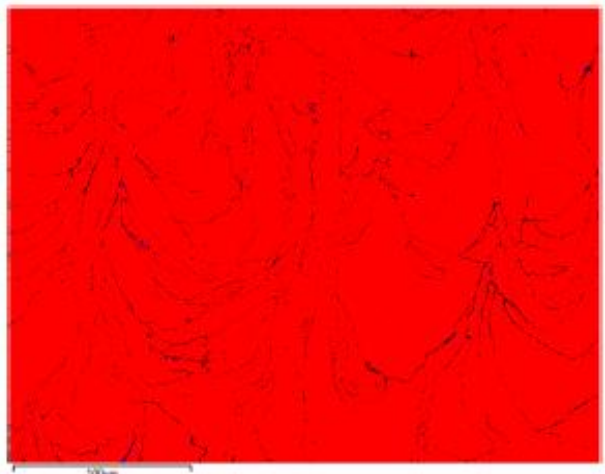

(b)

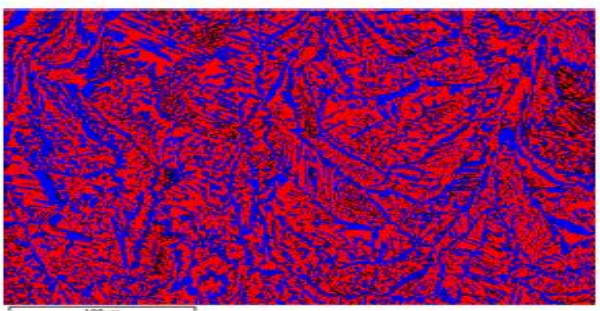

(d)

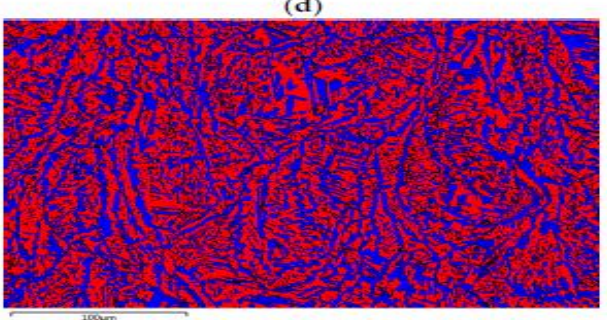

$(f)$

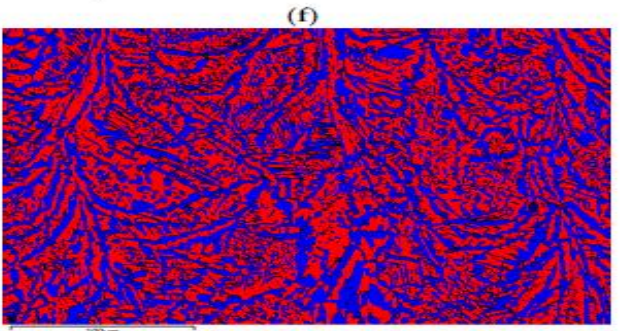

(h)
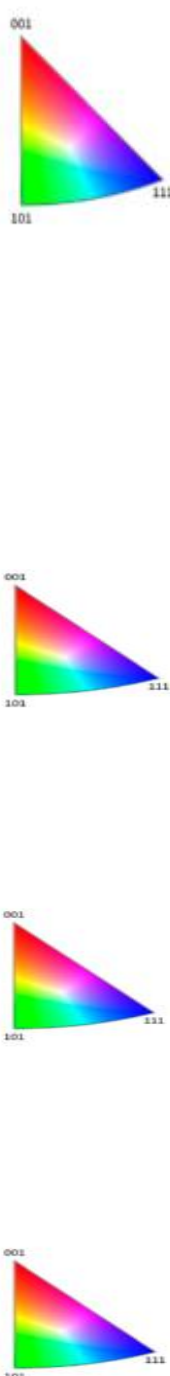

Figure 3. Specimen heat treated at $1000{ }^{\circ} \mathrm{C} / 5 \mathrm{~min}(\mathrm{c}, \mathrm{d})$, specimen heat treated at $1050{ }^{\circ} \mathrm{C} / 5 \mathrm{~min}(\mathrm{e}, \mathrm{f})$, and specimen heat treated at $1000{ }^{\circ} \mathrm{C} / 60 \mathrm{~min}(\mathrm{~g}, \mathrm{~h})$. EBSD inverse pole figures (a,c,e,g) and phase maps (b,d,f,h) of the as-built specimen with $66^{\circ}$ scanning rotation $(\mathrm{a}, \mathrm{b})[5]$.

Suvi Papula et al. discussed the austenite volume fractions for heat-treated specimens. The content of austenite for the annealing temperature ranging from $950^{\circ} \mathrm{C}$ to $1150^{\circ} \mathrm{C}$ is over 40 percent. For a longer annealing time of 60 minutes, the austenite content rises by up to 46.4 percent. In the temperature range of $1000^{\circ} \mathrm{C}$ to $1050^{\circ} \mathrm{C}$, Suvi Papula et al. concluded that the maximum austenite content was observed [5].

Suvi Papula et al., in their publication, concluded that due to high dislocation density and nitride precipitates formation, the as-built specimen shows high yield and tensile strength but less ductility [5]. The tensile and yield strength values are considerably higher for heattreated DSS specimens because of the microstructure's small phase size.

For the SLM processed as-built material, the pitting breakdown potential (Epit) observed is $0.4 \mathrm{~V}_{\text {SCE }}$ for the potential range between $300 \mathrm{Mv}$ below OCP up to $1.0 \mathrm{VSCE}$. When the polarization direction was reversed, the marked hysteresis was observed, and the return polarization curve followed an active path. Due to the material porosity, the re-passivation potential reduced in as-built SLM processed material (Figure 4). The pitting corrosion 
resistance of SLM samples significantly increased due to consecutive heat treatment. The asbuilt DSS specimen was almost 99 percent ferritic, and on successive heat treatment, the austenite content increased up to 46 percent. DSS's corrosion resistance is greater than the single-phase ferritic and austenitic steels in chloride-rich surroundings.

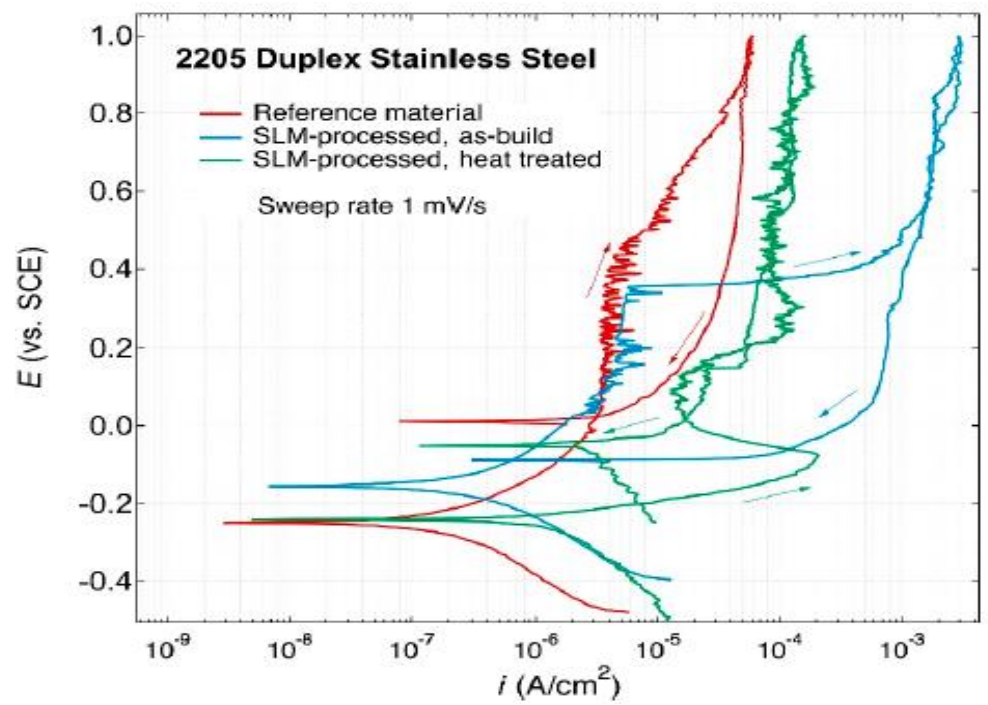

Figure 4. Cyclic potentiodynamic polarization curves for as received 2205 DSS, SLM processed as-built 2205 DSS, and SLM processed heat treated 2205 DSS [5].

Bajaj et al. reported the mechanical properties of various chrome steel grades [6]. They concluded that the range of ultimate enduringness varies with variation within the elongation for conventionally processed duplex stainless steels. Except for the AM processed duplex chrome steel, the range of ultimate enduringness is sort of constant with variation within the elongation.

\section{Challenges of Additive Manufacturing}

\subsection{Void formation.}

This issue emerges as a result of decreased holding between progressive surfaces and prompts substandard mechanical execution. The measure of porosity incited additionally relies on the development of voids during the AM cycle.

\subsection{Stair stepping.}

Step Stepping is identified with the layering defects in the created parts. This kind of blunder is deficient for inside manufactured layers and causes an extraordinary effect on item quality [7].

\subsection{Anisotropic mechanical properties and microstructure.}

A large portion of the AM advances parts are delivered layer by layer and this will bring about the development of warm angle [7]. AM handled parts have various properties and microstructure along the build direction and other directions.

\subsection{Small build volume.}

Additive manufacturing technologies are possibly implied for building more modest 
volumes, and if we need to assemble an immense segment, we need to downsize the segment or cut into subparts. But in most cases scaling down the model is not feasible and effective.

\section{Mechanical Alloying approach to prepare metal powders}

Ball milling is a high-energy technique that falls under the mechanical alloying group [8]. The milling balls' effect deforms the powder particles and then plastically deforms the powder particles, forming new surfaces and allowing the particles to weld together.

Stainless steels are divided into four main families based on their microstructure: ferritic, austenitic, martensitic, and duplex stainless steel. Duplex stainless steels have a balanced proportion of ferrite and austenite phases [9]. They have strong corrosion resistance and are resistant to pitting corrosion and stress corrosion cracking in several environments [9].

As materials are reduced to the nanoscale, their properties improve dramatically, according to Shashanka et al. [10]. As a result, they used a high-energy planetary milling method to prepare and synthesize DSS powders. According to Shashanka et al., planetary milling $[10,13,14]$ is one of the most basic and commonly used plastic deformation methods for achieving extreme refinement in material structure. After 10 hours of subsequent milling in a Dual Drive Planetary Mill, Shashanka et al. developed nanostructured DSS powders (DDPM) [15-22].

According to the authors, the importance of nano $\mathrm{Y}_{2} \mathrm{O}_{3}$ additions to DSS powders was stated by Shashanka et al. The addition of $\mathrm{Y}_{2} \mathrm{O}_{3}$ increases the density and hardness significantly, according to the authors [11]. The experiment also demonstrates that yttria's addition increases phase change from $\alpha-\mathrm{Fe}$ to $\gamma-\mathrm{Fe}$. The dry and wet ball milling results were also examined by Shashanka et al. They concluded that dry milling produces spherical stainless-steel powders, while wet milling produces irregularly formed particles. When stainless-steel samples are milled in an argon atmosphere, they have smaller particles, smaller crystallites, and higher lattice strain than when milled in a toluene atmosphere [12]. The authors concluded that the milling atmosphere is critical in grinding powder size, morphology, and phase change.

\section{Conclusions}

Additive manufacturing techniques allow for high levels of personalization and customization while reducing manufacturing complexity and expense. Selective laser melting (SLM) can be used for applications that require high-level component power. A wide variety of metals, metallic alloys, ceramics, and polymers can be used to produce a wide range of biocompatible materials. The arrangement of austenite-ferrite for the SLM processed DSS is balanced upon subsequent heat-treatment. With excellent mechanical properties, the porosity of the SLM processed SAF 2205 DSS was 0.03 percent. SAF 2205 DSS pitting corrosion resistance was increased following successive thermal treatment. In chloride-rich conditions, the SAF 2205 DSS grade has greater corrosion resistance. Stainless steel produced by additive manufacturing has superior corrosion properties to stainless steel produced traditionally. The hardness and tensile strength of steel produced by AM equal to or exceeds that of steel produced conventionally. Design versatility, product customization, and the ability to create complex structures are only a few of AM technology's advantages. Some drawbacks require improvement and careful examination, such as small part size, anisotropic mechanical properties, high costs, gaps in the top layers, and over-extrusion. 
Table 5. Studies related to various AM Processes.

\begin{tabular}{|c|c|c|c|c|}
\hline Author & Year & Objective & Method & Work Material \\
\hline $\begin{array}{l}\text { Karl Davidson et al. } \\
\text { [23] }\end{array}$ & 2015 & $\begin{array}{l}\text { To prepare fully } \\
\text { dense solid parts } \\
\text { without significant } \\
\text { losses in mechanical } \\
\text { properties }\end{array}$ & $\begin{array}{l}\text { Selective Laser } \\
\text { Melting }\end{array}$ & SAF 2507 \\
\hline $\begin{array}{l}\text { Karl Davidson et al. } \\
\text { [24] }\end{array}$ & 2016 & $\begin{array}{l}\text { To achieve strong, } \\
\text { soft magnetic } \\
\text { characteristics }\end{array}$ & $\begin{array}{l}\text { Selective Laser } \\
\text { Melting }\end{array}$ & SAF 2507 \\
\hline K Saeidi et al. [25] & 2016 & $\begin{array}{l}\text { To obtain superior } \\
\text { mechanical properties }\end{array}$ & $\begin{array}{l}\text { Selective Laser } \\
\text { Melting }\end{array}$ & SAF 2507 \\
\hline $\begin{array}{l}\text { Wu, Wenjin et al. } \\
\text { [26] }\end{array}$ & 2016 & $\begin{array}{l}\text { To achieve better } \\
\text { mechanical and } \\
\text { corrosion properties }\end{array}$ & $\begin{array}{l}\text { Selective Laser } \\
\text { Melting }\end{array}$ & $\begin{array}{l}\text { SS316L, SS304L, } \\
\text { SS-420 and SAF } \\
2507\end{array}$ \\
\hline $\begin{array}{l}\text { Karl Davidson et al. } \\
\text { [27] }\end{array}$ & 2017 & $\begin{array}{l}\text { To obtain strong } \\
\text { columnar } \\
\text { microstructure and } \\
\text { fine cellular internal } \\
\text { grain structure }\end{array}$ & $\begin{array}{l}\text { Selective Laser } \\
\text { Melting }\end{array}$ & SAF 2507 \\
\hline $\begin{array}{l}\text { Gerhard Posch et al. } \\
\text { [28] }\end{array}$ & 2017 & $\begin{array}{l}\text { To achieve better } \\
\text { surface roughness } \\
\text { and enhancement in } \\
\text { strength and } \\
\text { toughness }\end{array}$ & $\begin{array}{l}\text { Wire Arc Additive } \\
\text { Manufacturing }\end{array}$ & G $2293 \mathrm{~N} \mathrm{~L}$ \\
\hline Cem Ornek [29] & 2018 & $\begin{array}{l}\text { To obtain controlled } \\
\text { microstructure to get } \\
\text { reproducible } \\
\text { properties }\end{array}$ & $\begin{array}{l}\text { Selective Laser } \\
\text { Melting }\end{array}$ & SAF 2507 \\
\hline $\begin{array}{l}\text { Adebola Adeyemi } e t \\
\text { al. [30] }\end{array}$ & 2018 & $\begin{array}{l}\text { To enhance wear } \\
\text { resistance, strength } \\
\text { property and } \\
\text { improvements in } \\
\text { product performance }\end{array}$ & $\begin{array}{l}\text { Selective Laser } \\
\text { Melting and Selective } \\
\text { Laser Sintering }\end{array}$ & SS316L \\
\hline $\begin{array}{l}\text { Magnus Eriksson et } \\
\text { al. [31] }\end{array}$ & 2018 & $\begin{array}{l}\text { To decrease weld } \\
\text { defects and to } \\
\text { enhance mechanical } \\
\text { properties }\end{array}$ & $\begin{array}{l}\text { Wire Arc Additive } \\
\text { Manufacturing }\end{array}$ & SAF 2507 \\
\hline $\begin{array}{l}\text { Vahid A Hosseini et } \\
\text { al. [32] }\end{array}$ & 2019 & $\begin{array}{l}\text { To develop the } \\
\text { continuous running } \\
\text { system to minimize } \\
\text { the production time } \\
\text { and to achieve the } \\
\text { highest deposition } \\
\text { rate }\end{array}$ & $\begin{array}{l}\text { Wire Arc Additive } \\
\text { Manufacturing }\end{array}$ & 2209 DSS \\
\hline $\begin{array}{l}\text { Majid Laleh } \text { et al. } \\
\text { [33] }\end{array}$ & 2019 & $\begin{array}{l}\text { To enhance hardness } \\
\text { and pitting corrosion } \\
\text { resistance }\end{array}$ & $\begin{array}{l}\text { Selective Laser } \\
\text { Melting }\end{array}$ & SS316L \\
\hline Fen Shang et al. [34] & 2019 & $\begin{array}{l}\text { To enhance } \\
\text { compressive } \\
\text { mechanical properties } \\
\text { and pitting resistance }\end{array}$ & $\begin{array}{l}\text { Selective Laser } \\
\text { Melting }\end{array}$ & UNS S32707 HDSS \\
\hline $\begin{array}{l}\text { Greg N. Nigon et al. } \\
\text { [35] }\end{array}$ & 2020 & $\begin{array}{l}\text { To obtain finer grain } \\
\text { orientation }\end{array}$ & $\begin{array}{l}\text { Selective Laser } \\
\text { Melting }\end{array}$ & 2205 DSS \\
\hline $\begin{array}{l}\text { Majid Laleh } \text { et al. } \\
\text { [36] }\end{array}$ & 2020 & $\begin{array}{l}\text { To obtain higher } \\
\text { pitting corrosion } \\
\text { resistance and unique } \\
\text { microstructural } \\
\text { features }\end{array}$ & $\begin{array}{l}\text { Selective Laser } \\
\text { Melting }\end{array}$ & SS316L, 2205 DSS \\
\hline $\begin{array}{l}\text { R Keshavamurthy et } \\
\text { al. [37] }\end{array}$ & 2020 & $\begin{array}{l}\text { To enhance the } \\
\text { friction and wear } \\
\text { properties of ABS }\end{array}$ & $\begin{array}{l}\text { Fused Deposition } \\
\text { Modelling }\end{array}$ & $\begin{array}{l}\text { Acrylonitrile } \\
\text { Butadiene } \\
\text { Styrene }(\mathrm{ABS})+2.5 \\
\mathrm{wt} \% \mathrm{Cu}, \mathrm{ABS}+5 \mathrm{wt} \% \\
\mathrm{Cu}\end{array}$ \\
\hline $\begin{array}{l}\text { Wanwan Jin et al. } \\
{[38]}\end{array}$ & 2020 & $\begin{array}{l}\text { To reduce residual } \\
\text { stress and distortion }\end{array}$ & $\begin{array}{l}\text { Wire Arc Additive } \\
\text { Manufacturing }\end{array}$ & SS316L, 2209DSS \\
\hline $\begin{array}{l}\text { Malin Lervag et al. } \\
\text { [39] }\end{array}$ & 2020 & $\begin{array}{l}\text { To reduce weld } \\
\text { defects and the } \\
\text { formation of } \\
\text { intermetallic phases }\end{array}$ & $\begin{array}{l}\text { Wire Arc Additive } \\
\text { Manufacturing }\end{array}$ & $2507 \mathrm{DSS}$ \\
\hline
\end{tabular}




\begin{tabular}{l|l|l|l|l}
\hline Author & Year & Objective & Method & Work Material \\
\hline $\begin{array}{l}\text { Pratik Murkute } \text { et al. } \\
{[40]}\end{array}$ & 2020 & $\begin{array}{l}\text { To produce } \\
\text { corrosion-resistant } \\
\text { SDSS clads with } \\
\text { higher pitting and } \\
\text { stress corrosion } \\
\text { cracking resistance }\end{array}$ & $\begin{array}{l}\text { Laser Powder Bed } \\
\text { Fusion }\end{array}$ & SAF 2507 \\
& & $\begin{array}{l}\text { To increase } \\
\text { microhardness and } \\
\text { tensile strength of } \\
\text { Intensive Dual-phase } \\
\text { steel alloy (IDP) } \\
\text { powders }\end{array}$ & $\begin{array}{l}\text { Laser Additive } \\
\text { Manufacturing }\end{array}$ & \\
\hline Jia-Hao Wen et al. & 2020 & & & \\
{$[41]$} & & & & \\
& & &
\end{tabular}

\section{Funding}

This research did not receive any specific grant from funding agencies in the public, commercial, or not-for-profit sectors.

\section{Acknowledgments}

The authors declare no acknowledgments.

\section{Conflicts of Interest}

The authors declare that they have no known competing financial interests or personal relationships that could have influenced the work reported in this paper.

\section{References}

1. Azam, F.I.; Rani, A.M.A.; Altaf, K.; Rao, T.V.V.L.N; Zaharin, H.A. An In-Depth Review on Direct Additive Manufacturing of Metals. IOP Conf. Series: Materials Science and Engineering 2018, 1-8. https://doi.org/10.1088/1757-899X/328/1/012005.

2. Noll, I.; Bartel, T.; Menzel, A. A computational phase transformation model for selective laser melting processes. Computational Mechanics 2020, 1321-1342. https://doi.org/10.1007/s00466-020-01903-4.

3. Bartolo, P.; Kruth, J.P.; Silva, J.; Levy, G.; Malshe, A; Rajurkar, K.; Mitsuishi, M.; Ciurana, J.; Leu, M. Biomedical production of implants by additive electro-chemical and physical processes. CIRP Annals Manufacturing Technology 2012, 1-21, http://dx.doi.org/10.1016/j.cirp.2012.05.005.

4. Hengsbach, F.; Koppa, P.; Duschik, K.; Holzweissig, M.J.; Burns; Nellesen, J.; Tillmann, W.; Troster, T.; Hoyer, K.P.; Schaper, M. Duplex stainless steel fabricated by selective laser melting - Microstructural and mechanical properties. Materials \& Design 2017, https://doi.org/10.1016/j.matdes.2017.07.046.

5. Papula, S.; Song, M.; Pateras, A.; Chen, X.B.; Brandt, M.; Easton, M.; Yagodzinskyy, Y.; Virkkunen, I.; Hanninen, H. Selective Laser Melting of Duplex Stainless Steel 2205: Effect of Post-Processing Heat Treatment on Microstructure, Mechanical Properties, and Corrosion Resistance. Materials 2019, 1-15. https://doi.org/doi:10.3390/ma12152468.

6. P. Bajaj; A. Hariharan; A. Kini; P. Kürnsteiner; D. Raabe; E.A. Jagle. Steels in additive manufacturing: A review of their microstructure and properties. Materials Science \& Engineering A 2019, 1-53, https://doi.org/10.1016/j.msea.2019.138633.

7. Abdulhameed, O.; Al-Ahmari, A.; Ameen, W.; Mian, S.H. Additive manufacturing: Challenges, trends, and applications. Recent Trends in Design and Additive Manufacturing - Research Article, Advances in Mechanical Engineering 2018, 1-27, https://doi.org/10.1177/1687814018822880.

8. Mahale, R.S.; Shamanth, V.; Sharath, P.C.. Processing and characterization of duplex stainless steels. Lecture Notes in Mechanical Engineering. Springer Nature Singapore Pte Ltd. 2021, 210-219, https://doi.org/10.1007/978-981-15-7557-0_20.

9. Mahale, R.S.; Shamanth, V.; Sharath, P.C.; Shashanka, R.; Hemanth, K.; "A review on spark plasma sintering of duplex stainless steels", Proceedings of $4^{\text {th }}$ International Conference on Advanced Research in Mechanical, Materials and Manufacturing Engineering 2020, 1-7, 
https://doi.org/10.1016/j.matpr.2020.10.357.

10. Shashanka, R.; Chaira, D. Optimization of milling parameters for the synthesis of nanostructured duplex and ferritic stainless-steel powders by high energy planetary milling. Powder Technology 2015, 35-45 http://dx.doi.org/10.1016/j.powtec.2015.03.007.

11. Shashanka, R.; Chaira, D. Effects of Nano- $\mathrm{Y}_{2} \mathrm{O}_{3}$ and Sintering Parameters on the Fabrication of PM Duplex and Ferritic Stainless Steels. Acta Metall. Sin. (Engl. Lett.) 2015, https://doi.org/10.1007/s40195-015-03621 .

12. Shashanka, R.; Uzun, O.; Chaira, D. Synthesis of Nano-Structured Duplex and Ferritic Stainless-Steel Powders by dry milling and Its comparison with wet milling. Arch. Metall. Mater 2020, 5-14. https://doi.org/10.24425/amm.2019.131091.

13. Shashanka, R.; Chaira, D. Development of nanostructured duplex and ferritic stainless steels by pulverisette planetary milling followed by pressure less sintering. Materials Characterization 2015, 220-229. http://dx.doi.org/10.1016/j.matchar.2014.11.030.

14. Shamanth, V.; Kumar, P.; Ravishankar, K.S. Effect of Heat Treatment on the High Cycle Fatigue Behaviour of S2205 Duplex Stainless Steels. Selection and Peer-review under responsibility of Advanced Materials, Manufacturing, Management and Thermal Science (AMMMT 2016). 10798-10802.

15. Shashanka, R.; Chaira, D.; Kumara Swamy, B.E. Electrocatalytic Response of Duplex and Yittria Dispersed Duplex Stainless Steel Modified Carbon Paste Electrode in Detecting Folic Acid Using Cyclic Voltammetry, Int. J. Electrochem. Sci. 2015, 5586-5598.

16. Shashanka, R.; Chaira, D.; B.E. Kumara Swamy, Electrochemical investigation of duplex stainless steel at carbon paste electrode and its application to the detection of dopamine, ascorbic and uric acid, International Journal of Scientific \& Engineering Research 2015, 1863-1871.

17. Shashanka, R.; Chaira, D.; B.E. Kumara Swamy, Fabrication of yttria dispersed duplex stainless steel electrode to determine dopamine, ascorbic and uric acid electrochemically by using cyclic voltammetry, International Journal of Scientific \& Engineering Research 2016, 1275-1285.

18. Shashanka, R.; Chaira, D.; D. Chakravarty, Fabrication of Nano-Yttria Dispersed Duplex and Ferritic Stainless Steels by Planetary Milling Followed by Spark Plasma Sintering and Non-Lubricated Sliding Wear Behaviour Study, Journal of Materials Science and Engineering $B$ 2016, 111-125. https://doi.org/10.17265/2161-6221/2016.5-6.001.

19. Shashanka, R.; Chaira, D. Effect of sintering temperature and atmosphere on non-lubricated sliding wear of nano-yttria dispersed and yttria free duplex and ferritic stainless steel fabricated by powder metallurgy, Tribology Transactions 2017, 324-336.

20. Shashanka, R.. Synthesis of nanostructured stainless steel powder by mechanical alloying-an overview, International Journal of Scientific \& Engineering Research 2017, 588-594.

21. Shashanka, R. Effect of Sintering Temperature on the Pitting Corrosion of Ball Milled Duplex Stainless Steel by using Linear Sweep Voltammetry, Anal. Bioanal. Electrochem 2018, 349-361.

22. Shashanka, R. Non-lubricated dry sliding wear behavior of spark plasma sintered nanostructured stainless steel, J. Mater. Environ. Sci 2019, 767-777.

23. Davidson, K.P.; Singamneni, S.B. Selective Laser Melting of Duplex Stainless Steel Powders; an Investigation, Materials and Manufacturing Processes 2015, 1-44, https://doi.org/10.1080/10426914.2015.1090605.

24. Davidson, K.P.; Sigamneni, S.B. Magnetic Characterization of Selective Laser-Melted SAF 2507 Duplex Stainless Steel. The Minerals, Metals \& Materials Society 2016, 569-574, https://doi.org/10.1007/s11837016-2193-6.

25. Saeidi, K.; Kevetkova, L.; Lofaj, F.; Shen, Z. Novel ferritic stainless steel formed by laser melting from duplex stainless-steel powder with advanced mechanical properties and high ductility. Materials Sciences \& Engineering A 2016, 59-65, http://dx.doi.org/10.1016/j.msea.2016.04.027.

26. Wenjin, W.; Shu Beng, T.; Leong, K. F.; Chua, C.K.; Merchant; Amirali, A. State of the art review on Selective Laser Melting of Duplex Stainless Steel for future application in the marine industry. Proceedings of the $2^{\text {nd }}$ International Conference on Progress in Additive Manufacturing (Pro-AM 2016), 475-481.

27. Davidson, K.P.; Singamneni, S.B. Metallographic evaluation of duplex stainless-steel powders processed by Selective Laser Melting. Rapid Prototyping Journal 2017. https://doi.org/10.1108/RPJ-04-2016-0053.

28. Posch, G.; Chladil, K.; Chladil, H. Material properties of CMT- metal additive manufactured duplex stainlesssteel blade-like geometries. International Institute of Welding 2017. https://doi.org/10.1007/s40194-0170474-5. 
29. Ornek, C. Additive manufacturing - a general corrosion perspective. Corrosion Engineering, Science and Technology 2018. 1-5, https://doi.org/10.1080/1478422X.2018.1511327.

30. Adeyemi, A.; Akinlabi, E.T.; Mahamood, R.M. Powder Bed Based Laser Additive Manufacturing Process of Stainless Steel: A Review. Materials Today: Proceedings 2018. pp. 18510-18517.

31. Eriksson, M.; Lervag, M.; Sorensen, C; Robertstad, A ; Bronstad, B.M.; Nyhus, B; Aune, R.; Ren, X.; Akselsen, O.M. Additive manufacture of super duplex stainless steel using WAAM. MATEC Web of Conferences 2018, pp. 1-8. https://doi.org/10.1051/matecconf/201818803014.

32. Hosseini, V.A.; Hogstrom, M.; Hurtig, K.; Bermejo, M.A.V; Stridh, L.E.; Karlsson, L. Wire-arc additive manufacturing of a duplex stainless steel: thermal cycle analysis and microstructure characterization. Welding in the World 2019. 975-987. https://doi.org/10.1007/s40194-019-00735-y.

33. Laleh, M.; Hughes, A.E.; Xu, W.; Gibson, I.; Tan, M.Y. Unexpected erosion-corrosion behaviour of 316L stainless steel produced by selective laser melting. Corrosion Science 2019. 67-74. https://doi.org/10.1016/j.corsci.2019.04.028.

34. Shang, F.; Chen, X.; Wang, Z.; Ji, Z.; Ming, F.; Ren, S.; Qu, X. The Microstructure, Mechanical Properties, and Corrosion Resistance of UNS S32707 Hyper-Duplex Stainless Steel Processed by Selective Laser Melting. Metals 2019. https://doi.org/10.3390/met9091012.

35. Nigon, G.N.; Isgor, O.B.; Pasebani, S. The effect of annealing on the selective laser melting of 2205 duplex stainless steel: Microstructure, grain orientation, and manufacturing challenges. Optics and Laser Technology 2021. https://doi.org/10.1016/j.optlastec.2020.106643.

36. Laleh, M.; Hughes, A.E.; Xu, W.; Gibson, I.; Tan, M.Y. A critical review of corrosion characteristics of additively manufactured stainless steels. International Materials Reviews 2020. https://doi.org/10.1080/09506608.2020.1855381.

37. Keshavamurthy, R.; Tambrallimath, V.; Badari, A.; Krishna, A.R.; Pradeep Kumar G. S.; Jeevan, M.C. Friction and Wear Behaviour of Copper Reinforced Acrylonitrile Butadiene Styrene based Polymer Composite Developed by Fused Deposition Modelling Process. FME Transactions 2020. 543-550. https://doi.org/10.5937/fme2003543K.

38. Jin, W.; Zhang, C.; Jin, S.; Tian, Y.; Wellmann, D.; Liu, W. Wire Arc Additive Manufacturing of Stainless Steels: A Review. Appl. Sci. 2020. 10, 1563. https://doi.org/10.3390/app10051563.

39. Lervåg, M.; Sørensen, C.; Robertstad, A.; Brønstad, B. M.; Nyhus, B.; Eriksson, M.; Aune, R.; Ren, X.; Akselsen, O. M.; \& Bunaziv, I.Additive Manufacturing with Super duplex Stainless Steel Wire by CMT Process. Metals 2020. https://doi.org/10.3390/met10020272.

40. Murkute, P.; Pasebani, S.; Burkan Isgor, O. Metallurgical and Electrochemical Properties of Super Duplex Stainless Steel Clads on Low Carbon Steel Substrate produced with Laser Powder Bed Fusion. Scientific Reports 2020. https://doi.org/10.1038/s41598-020-67249-2.

41. Wen, J. H.; Zhang, L. J.; Ning, J.; Xue, F.; Lei, X. W.; Zhang, J. X.; \& Na, S. J. Laser additively manufactured intensive dual-phase steels and their microstructures, properties, and corrosion resistance. Materials and Design 2020. https://doi.org/10.1016/j.matdes.2020.108710. 